\title{
Photovoltaic System Integrated Into the Noise Barrier - Energy Performance and Life Cycle Assessment
}

\author{
Agata Zdyb ${ }^{1 *}$, Agnieszka Żelazna', Ewelina Krawczak ${ }^{1}$ \\ ${ }^{1}$ Faculty of Environmental Engineering, Lublin University of Technology, Nadbystrzycka 40B, 20-618 Lublin, \\ Poland \\ * Corresponding author's e-mail: a.zdyb@pollub.pl
}

\begin{abstract}
The presented work is devoted to the analysis of the performance of an installation comprising photovoltaic modules $(3.56 \mathrm{kWp})$ integrated into a noise barrier under temperate climate. The application of the DDS-Cad software enables to estimate the amount of electricity produced annually. The use of LCA (Life Cycle Assessment) method, based on the material and energy balance of the system, allows the ecological evaluation of the analyzed solution. The designed installation, in which the thin film cadmium telluride modules were applied, can produce $3390 \mathrm{kWh}$ of electric energy per year. This kind of photovoltaic system can be multiplied depending on the available number of acoustic panels oriented at the desired azimuth along the highway or railway.
\end{abstract}

Keywords: photovoltaics, noise barrier, Life Cycle Assessment, Global Warming Potential, IMPACT2002+

\section{INTORDUCTION}

In the light of growing global energy demand, the diversification of energy sources including the implementation of renewable sources, is extremely important. Among many renewable energy sources (RES), solar energy is the most abundant form, considered as environmentally and economically beneficial, which also enjoys public acceptance [Tsantopoulos et al. 2014]. A sustainable way of converting solar energy into electricity is provided by the photovoltaic (PV) technologies that gain popularity and contribute to the reduction of pollution emission [Dragan and Zdyb 2017, Żelazna et al. 2016].

PV modules can be applied in different ways, including the installations connected directly to the power grid (on-grid) and the systems independent of the grid (off-grid), which are usually equipped with their own energy storage device. Among many possibilities of PV modules mounting, the roof-top commercial and residential installations as well as large solar plants are the most popular. Taking into account the growing interest in the PV applications, seeking for new sites that are suitable for the PV installations is a very important issue. In this context, integration of solar modules with flat surfaces like building walls or noise barriers seems to be a promising solution [Wadhawan and Pearce 2017, Faturrochman 2018, Vallati et al. 2015, De Schepper et al. 2012]. Acoustic panels are dedicated to protect animals and people from the harmful influence of the noise coming from traffic, railway transport or industrial activities, and are widely used nowadays.

In the presented work, a PV installation integrated into a noise barrier was designed and energy analysis as well as Life Cycle Assessment (LCA) was performed. The cadmium telluride (CdTe) modules were chosen due to their high efficiency and dimensions allowing enabling them to be fitted well to an acoustic panel. The CdTe modules are manufactured in thin film technology and they belong to the second generation of solar modules. The main advantage of the thin film solar cell devices is lower materials usage and easier recycling comparing to the traditional silicon modules. This kind of modules is also frameless and resistant to the temperature growth under 
intensive solar radiation. Their temperature coefficient usually has beneficial value which is very important for the final energy yield, not only in warm climatic zones but also in temperate climate, where the modules can reach the temperature up to $50-60^{\circ} \mathrm{C}$. This type of modules has proven long-term reliability, so they are recommended for usage in high temperature, high humidity, extreme desert and also coastal environment.

\section{METHODS}

The presented study consists of two parts: the first pertains to the design and performance simulation of photovoltaic installation integrated with the noise barrier and the second is based on a Life Cycle Assessment of the system.

In the first part, a simulation with the use of DDS-Cad software was performed in order to design the photovoltaic system integrated with the noise barrier and to estimate energy yield. DDSCad is software which enables to design, simulate and visualize roof, facade or ground-mounted photovoltaic systems. Noise barriers are characterized by modular construction. Each of them is composed of two assemblies, which can be treated separately. In the simulated installation, a single noise barrier assembly is covered by four photovoltaic modules attached in two rows. The $3 \mathrm{D}$ visualization of the photovoltaic module arrangement is presented in Fig. 1. In the presented simulation, First Solar CdTe thin film modules are mounted horizontally on the top part of the noise barrier and oriented to the south. The modules are considered to be mounted facing the road, only on the one side of the noise barrier which helps to harvest the maximum solar irradiation.
The designed PV system is placed along the fast route in Warsaw $\left(52^{\circ} 27^{\prime} \mathrm{N} 20^{\circ} 98^{\prime} \mathrm{E}\right.$, height above sea level equals $130 \mathrm{~m}$ ). This location is characterized by the temperate climate. In summer, the temperatures vary from $25^{\circ} \mathrm{C}$ to $35^{\circ} \mathrm{C}$, while in winter, the average temperature is about $0^{\circ} \mathrm{C}$. The annual solar irradiation for the selected location is about $1065 \mathrm{kWh} / \mathrm{m}^{2}$, the average temperature equals $9^{\circ} \mathrm{C}$, whereas the average wind speed is $4 \mathrm{~m} / \mathrm{s}$. The meteorological data used in the simulation was implemented from Meteonorm 7.2 software.

The second part of the study was based on a Life Cycle Assessment [Asdrubali et al. 2015, Fthenakis et al. 2008, Ito et al. 2016] of the system described above and included four main stages:

1. Goal and Scope Definition,

2. Inventory Analysis,

3. Life Cycle Impact Assessment,

4. Interpretation.

In the first stage, the aim of the study was stated as the calculation of possible environmental effects of PV system performance by the use of Global Warming Potential and IMPACT2002+ methods. The functional unit was assumed as $1 \mathrm{kWh}$ of energy produced by photovoltaic installation.

The second stage, Inventory Analysis, was based on the material and energy balance of the system. It included detailed calculations of the materials used for installation of PV panels and inverter, cables, mounting system, maintenance of installation and final disposal including the transportation to the recycling point. The recycling processes were excluded from this study. For the production of panels, Ecoinvent database processes were used, including the production of CdTe laminate. The production of a PV panel was

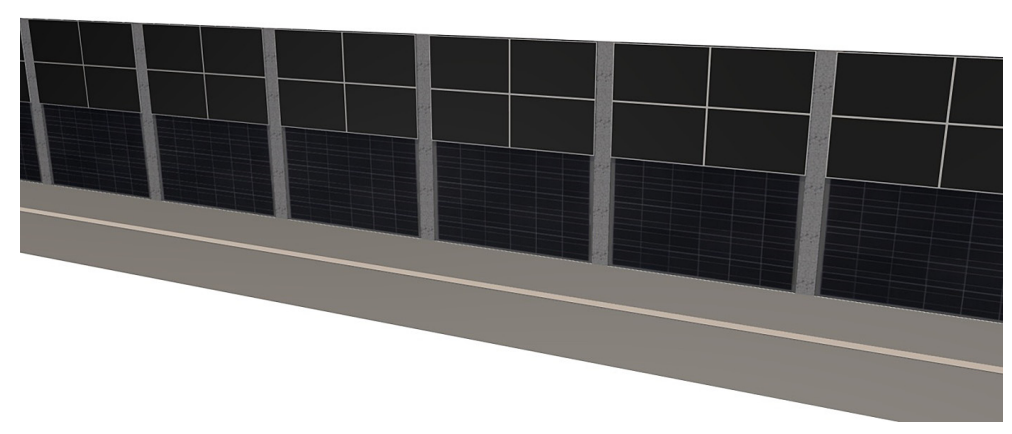

Fig. 1 Visualization of the horizontal configuration of the PV modules 
extrapolated from the crystal Si panel by means of recalculation of single elements like frames and coverings to the adequate mass and dimensions, including CdTe laminate (Ecoinvent v. 3, allocation, default - unit; attached to SimaPro v. 8.0.5.13). The mounting system balance was calculated separately since the designed PV panels are placed vertically on the sound barrier; therefore, the recycled aluminum frames and steel screw were the only elements used for connection. The installation maintenance included washing (20 kg of water per square meter of panels yearly) and one exchange of an inverter [Żelazna 2016]. Total service life time was assumed as 25 years, according to the warranty. The linear efficiency drop was assumed as $0.5 \%$, leading to the $86 \%$ of maximal efficiency after 25 years according to the producer's data.

The energy balance (possible energy output of the system) was modelled in DDS-Cad and then the Life Cycle Impact Assessment was performed with the use of Global Warming Potential and IMPACT 2002+ methods. Global Warming Potential in 100 years perspective results in the calculation of the greenhouse gas emission expressed as $\mathrm{kgCO}_{2 \mathrm{eq}}$ and includes the list of 204 substances potentially responsible for greenhouse effect. IMPACT $2002+$ is multi-dimensional method, including the wide range of environmental burdens calculated into eleven impact categories and four damage categories: Human Health, Ecosystem Quality, Climate Change and Resources. The result is expressed as points $(\mathrm{Pt})$ and allows tracking of the most significant unit processes in the analyzed system [Humbert et al. 2005].

The necessary calculations were performed using SimaPro v. 8. The results and their interpretation according to the $4^{\text {th }}$ stage are presented in the next chapter.

\section{RESULTS}

In order to simulate the energy yield, average monthly irradiation presented in Fig. 2 was used. The meteorological data is extremely important because the quantity of energy production is strongly influenced by the external conditions. Annual solar irradiation for the selected location is about $1065 \mathrm{kWh} / \mathrm{m}^{2}$, average temperature equals $9^{\circ} \mathrm{C}$.

In this case study, a small grid-connected system was projected. The use of high quality, thinfilm modules was assumed. The selected CdTe thin film modules are characterized by beneficial temperature coefficient in comparison with the first generation, silicon-based solar cells. The solar modules under the considered latitude can reach high temperatures, up to $50^{\circ} \mathrm{C}$ [Gułkowski et al. 2019, Zdyb and Krawczak 2017], high above $25^{\circ} \mathrm{C}$, determined by standard test conditions (STC). The selected modules are characterized by the temperature coefficients of nominal power, open-circuit voltage, and short circuit current are $-0.32 \% /{ }^{\circ} \mathrm{C},-0.28 \% /{ }^{\circ} \mathrm{C}$ and $+0.04 \% /{ }^{\circ} \mathrm{C}$ respectively. The designed PV installation consists of eight CdTe modules, four modules by

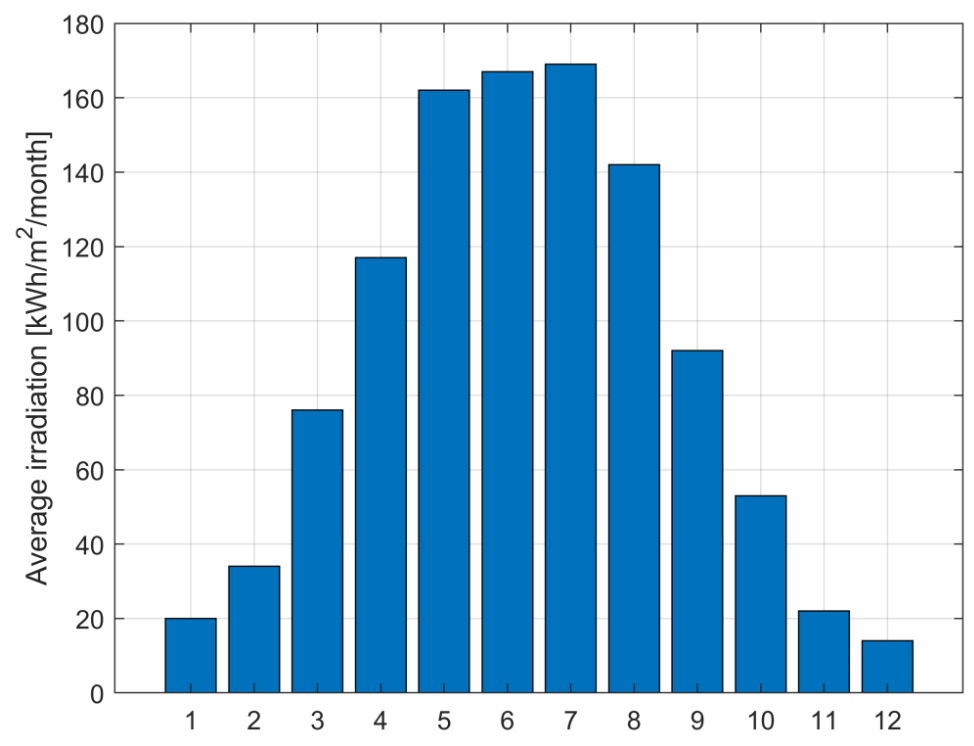

Fig. 2. Average monthly irradiation in the selected location, Warsaw, Poland. 
each noise barrier assembly, which results in the total installed capacity equal to $3.56 \mathrm{kWp}$. The performance parameters of the modules in standard test conditions are shown in Table 1.

The modules are connected into 4 strings with 2 modules on each, which are attached into 1 tracker. They are wired to the inverter which is characterized by the maximum $\mathrm{PV}$ power equal to $3.8 \mathrm{kWp}$, input voltage in the range of $125-600 \mathrm{~V}$, maximum input current about $11.5 \mathrm{~A}$. The inverter works with the maximum efficiency and European efficiency equal to $98 \%$ and $97.7 \%$, respectively. The chosen site of the installation is free from shadowing. Finally, the energy production (Fig. 3) estimation indicates the following values: DC energy production $3475 \mathrm{kWh} / \mathrm{a}$, AC energy production $3390 \mathrm{kWh} / \mathrm{a}$ and the specific energy production $952.2 \mathrm{kWh} / \mathrm{kWp} / \mathrm{a}$. During sunny and warm half of the year (April to October) the system produces $71 \%(2408 \mathrm{kWh})$ of the entire annual production, which is typical in temperate climate where significant weather differences are observed between both parts of the year.

Table 1. CdTe module specification.

\begin{tabular}{|c|c|c|}
\hline Module type & & CdTe \\
\hline \multicolumn{3}{|c|}{ STC : $1,000 \mathrm{~W} / \mathrm{m}^{2}, 25^{\circ} \mathrm{C}, \mathrm{AM} 1.5$} \\
\hline Peak power output watt [Wp] & $P_{\max }$ & 445 \\
\hline Short circuit current $[\mathrm{A}]$ & $I_{s c}$ & 2.56 \\
\hline Open circuit voltage [V] & $V_{o c}$ & 220.4 \\
\hline Current at $\mathrm{P}_{\text {MAX }}[\mathrm{A}]$ & $I_{\text {MAX }}$ & 2.40 \\
\hline Voltage at $\mathrm{P}_{\mathrm{MAX}}[\mathrm{V}]$ & $V_{\text {MAX }}$ & 185.7 \\
\hline \multicolumn{2}{|l|}{ Module efficiency } & $18.00 \%$ \\
\hline \multicolumn{2}{|l|}{ Dimensions $(H \times W \times D)[m m]$} & $2009 \times 1232 \times 49$ \\
\hline
\end{tabular}

Ensuring the proper ventilation on the back side of the modules in order to avoid harmful overheating is a significant factor that influences the final yield in the case of modules mounted on the acoustic panels. The modules can thus be installed with a small distance from the surface of noise barrier or they can be completely integrated with the panel playing the role of noise barrier. It is also possible to install the modules on a special mounting system at the inclination angle optimal for given localization, which allows the air to easily flow and cool the backside of the modules. However, but this solution involves the risk of modules uplift due to extreme windy weather. It is also worth to emphasize that the inclination of the modules at the angle of $90^{\circ}$ results in the decrease of energy production comparing to the optimal angle at the given latitude, but it can be beneficial since it allows to avoid the loses from residual snow or dust shedding.

The calculations of carbon footprint according to the GWP100a methodology resulted in total sum of indicator equal $945.15 \mathrm{kgCO}_{2 \mathrm{eq}}$, which in relation to the functional unit is equal $0.012 \mathrm{kgCO}_{2 \mathrm{eq}} / \mathrm{kWh}$. The analysis of shares show that nearly $67 \%$ of that value is connected with the production and mounting of PV system. Maintenance, in particular the exchange of inverter, corresponds to another $33 \%$. The particular elements of system and corresponding indicators are presented in Fig. 4.

According to the data included in the Ecoinvent database, utilization of the typical energy unit in Polish low-voltage electrical grid corresponds to the emission of $1.17 \mathrm{kgCO}_{2 \mathrm{eq}}$; therefore,

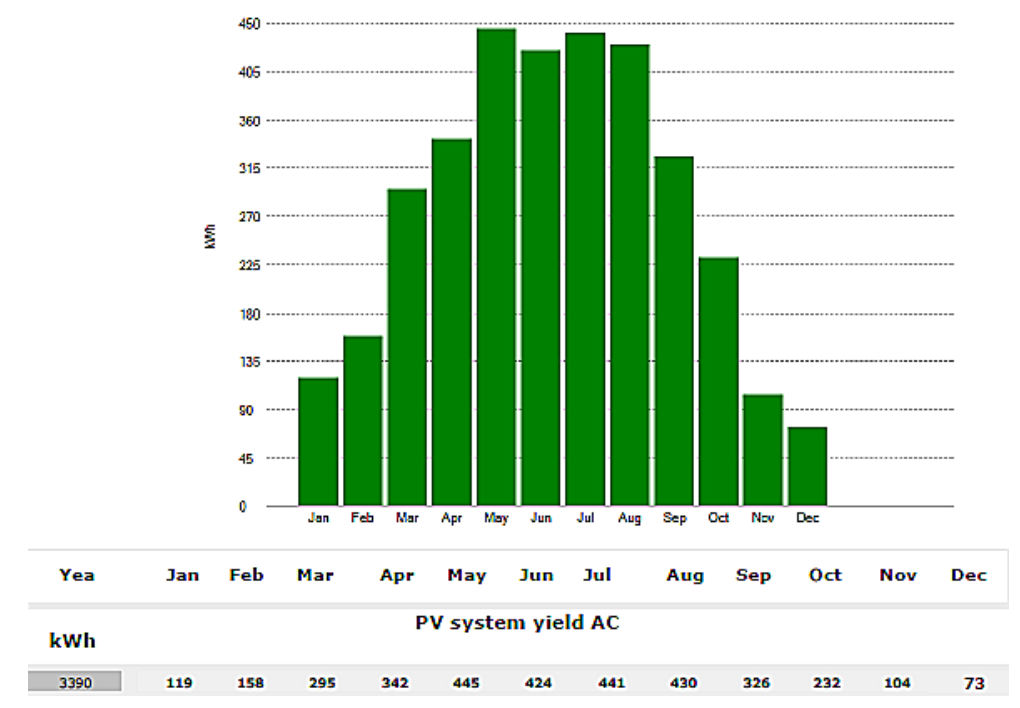

Fig. 3. Electric energy production in the noise barrier integrated PV system 


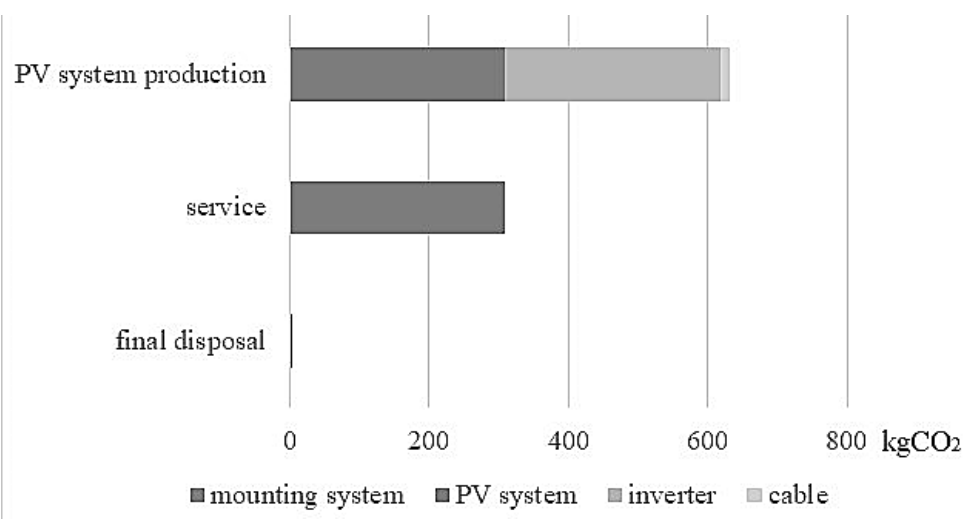

Figure 4. GWP100a results divided into elements of the PV system's life cycle, $\mathrm{kgCO}_{2 \mathrm{eq}}$.

the energy produced by the analyzed PV system could bring the significant reduction of the greenhouse gas emission. However, it has to be mentioned that the calculated data for the PV system does not include the energy transportation losses. Therefore, the more accurate data could be found in [Żelazna, 2016], where $1 \mathrm{kWh}$ of energy in Polish energy mix generates $0.831 \mathrm{kgCO}_{2 \mathrm{eq}}$. Concerning this, utilization of the PV energy produced by the system contributes to the significant reduction of GHG emission.

The calculations of IMPACT2002+ resulted in total sum of indicator equal $545.95 \mathrm{mPt}$, which in relation to the functional unit is equal to $0.07 \mathrm{mPt} / \mathrm{kWh}$. The analysis of shares on the process level show that nearly $66 \%$ of that value is connected with the production and mounting of PV system, while the maintenance corresponds to the another $34 \%$. The particular elements of system and corresponding indicators are presented in Figure 5.

The analysis of shares on the impact category level show that Human Health is the most important category with nearly $50 \%$ share in the total value of the indicator. Category Resources corresponds to the another 20\%, while Climate Change and Ecosystem Quality are responsible for $18 \%$ and $12 \%$ of the value, respectively. The detailed investigation shows that the most important emissions include the substances strictly connected with conventional energy sources, like carbon dioxide, nitrogen oxides, sulphur dioxide and particulates, which correspond to over $53 \%$ of total indicator value. The metals used in production are the second important group, which is responsible for $12 \%$ of IMPACT $2002+$ indicator.

\section{CONCLUSIONS}

The utilization of noise barriers as a site for PV installation mounting is an interesting solution, taking into account that this kind of system always requires large flat surfaces. It seems that the important issue in the PV applications of this type is identification of the existing noise barriers which are oriented to the south and determination of their length. The lack of properly situated barriers can be the main limitation in the investment but the orientation of the modules at east-west azimuth on both sides of the barrier or usage of bifacial modules can also be considered. Under the actual conditions, when the photovoltaic installations are planned to be mounted on the noise

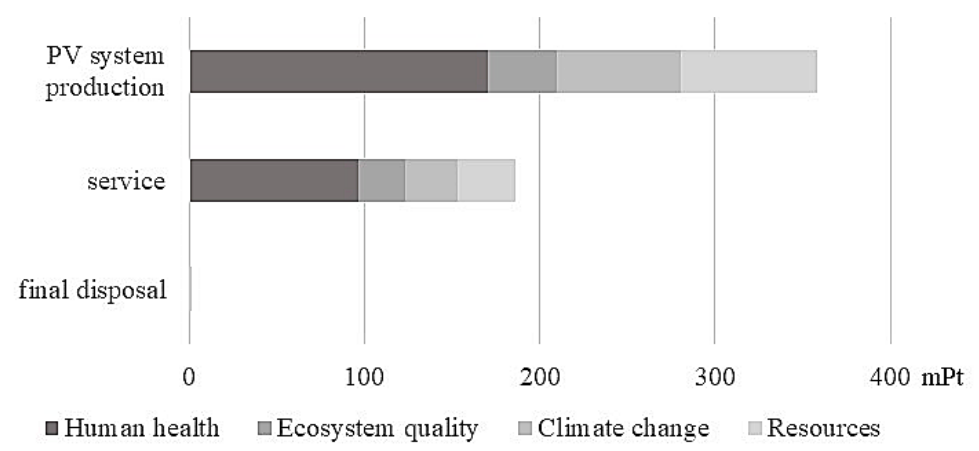

Figure 5. IMPACT 2002+ results divided into elements of the PV system life cycle, $\mathrm{kgCO}_{2 \mathrm{eq}}$. 
barriers along a highway or railway, the described installation can be multiplied depending on the length of the road or the number of the modules can be increased and then they can be connected to one bigger inverter.

The planned photovoltaic installation of $3.56 \mathrm{kWp}$ power consists of CdTe modules and in spite of the slope equal to $90^{\circ}$, it can produce $3390 \mathrm{kWh}$ of electric energy per year. Undoubtedly, a significant factor in this study is the application of high quality modules, which according to the manufacturer's data generate up to $8 \%$ more energy than a typical Si module as well as exhibit superior spectral response and performance that exceeds typical yields under extreme external conditions.

The LCA analysis indicated that the environmental impact of the considered photovoltaic installation is low, the harness of solar energy leads to the reduction of harmful chemicals emission and can be treated as a valuable contribution in the introduction of sustainable development concept. The determined values of indicators could be even lower if recycling of modules -reaching $99 \%$ - was taken into account.

\section{REFERENCES}

1. Asdrubali F., Baldinelli G., D’Alessandro F., Scrucca F.2015. Life cycle assessment of electricity production from renewable energies: Review and results harmonization. Renewable and Sustainable Energy Reviews, 42, 1113-1122.

2. De Schepper E., Van Passel S., Manca J., Thewys T. 2012. Combining photovoltaics and sound barriers a feasibility study. Renewable Energy, 46, 297-303.

3. Dragan P., Zdyb A. 2017. Reduction of Pollution Emission by Using Solar Energy in Eastern Poland. Journal of Ecological Engineering, 18, 231-235.

4. Faturrochman G.J., de Jong M.M., Santbergen R., Folkerts W., Zeman M., Smets A.H.M. 2018,
Maximizing annual yield of bifacial photovoltaics noise barriers. Solar Energy, 162, 300-305.

5. Fthenakis V.M., Kim H.C., Alsema E. 2008. Emissions from Photovoltaic Life Cycles. Environmental Science Technology, 42, 2168-2174.

6. Gułkowski S., Zdyb A., Dragan P. 2019. Experimental Efficiency Analysis of a Photovoltaic System with Different Module Technologies under Temperate Climate Conditions. Applied Sciences, 9, 141-154.

7. Humbert S., Margni M., Jolliet O. 2005. IMPACT 2002+: User Guide, Industrial Ecology \& Life Cycle Systems Group, Swiss Federal Institute of Technology Lausanne (EPFL).

8. Ito M ., Lespinats S., Merten J., Malbranche P., Kurokawa K. 2016. Life cycle assessment and cost analysis of very large-scale PV systems and suitable locations in the world. Progress in Photovoltaics, 24, 159-174.

9. Tsantopoulos G., Arabatzis G., Stilianos T. 2014. Public attitudes towards photovoltaic developments: case study from Greece. Energy Policy, 71, 94-106.

10. Vallati A., de Lieto Vollaro R., Tallini A., Cedola L. 2015. Photovoltaic Noise Barrier: Acoustic and Energetic Study. Energy Procedia, 82, 716-723.

11. Wadhawan S.R., Pearce J.M. 2017. Power and Energy potential of mass-scale photovoltaic noise barriee deployment: A case study for the U.S. Renewable and Sustainable Energy Reviews, 80, 125-132.

12.Zdyb A., Krawczak E. 2017. The influence of external conditions on the photovoltaic modules performance. Environmental Engineering V, eds.: M. Pawłowska, L. Pawłowski, CRC Press Taylor\&Francis Group, 261-266.

13. Żelazna A., 2016. Ocena zrównoważoności systemów solarnych oparta na analizie cyklu życia. Monografie Komitetu Inżynierii Środowiska PAN, 125, Lublin.

14. Żelazna A., Zdyb A., Pawłowski A. 2016. The influence of selected factors on PV systems environmental indicators, Rocznik Ochrona Środowiska, 18, 722-732. 